\title{
Serotyping HIV-1 with V3 peptides: detection of high avidity antibodies presenting clade-specific reactivity
}

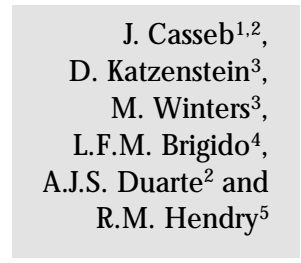

\author{
${ }^{1}$ Instituto de Infectologia "Emílio Ribas", São Paulo, SP, Brasil \\ ${ }^{2}$ Laboratório de Alergia e Imunologia Clínica, Faculdade de Medicina, \\ Universidade de São Paulo, São Paulo, SP, Brasil \\ ${ }^{3}$ Center for AIDS Research, Stanford U niversity, Stanford, CA, USA \\ ${ }^{4}$ Instituto Adolfo Lutz, São Paulo, SP, Brasil \\ ${ }^{5}$ Viral and Rickettsial D iseases Laboratory, California Department of Health Services, \\ Berkeley, CA, USA
}

\section{Correspondence \\ J. Casseb \\ Laboratório de Alergia e \\ Imunologia Clínica, FM, USP \\ Av. Dr. Arnaldo, 455 \\ 20 andar, Sala 2345 \\ 01246-903 São Paulo, SP \\ Brasil \\ J. Casseb was the recipient \\ of a fellowship from the \\ Fogarty International AIDS \\ Training Program (TW \# 00003), \\ University of California, \\ Berkeley, CA, USA. \\ The current address of R.M. Hendry is \\ Wyeth-Lederle Vaccines, New York, \\ NY, USA. \\ Publication supported by FAPESP.}

Received March 27, 2001

Accepted December 11, 2001

\section{Abstract}

The main objective of the present study was to assess the specificity and sensitivity of a modified assay using short synthetic peptides of the V3 region of HIV-1 gp120, which is the main target for neutralizing antibodies. Results from an enzyme immunoassay (EIA) employing a panel of synthetic peptides of HIV-1 subtypes and using urea washes to detect high avidity antibodies (AAV3) were compared with those obtained by the heteroduplex mobility assay and DNA sequencing. The EIA correctly typed $100 \%$ of subtype B (sensitivity $=1.0$; specificity $=0.95), 100 \%$ of HIV-1 E samples (sensitivity $=1.0$; specificity $=1.0$ ), and $95 \%$ of subtype $\mathrm{C}$ specimens ( (sensitivity $=0.95$; specificity $=0.94)$. In contrast, only $50 \%$ of subtype A (sensitivity $=$ 0.5 ; specificity $=0.95), 60 \%$ of subtype $\mathrm{D}$ (sensitivity $=0.6$; specificity $=1.0$ ), and $28 \%$ of subtype F samples (sensitivity $=0.28$; specificity $=0.95$ ) were correctly identified. This approach was also able to discriminate in a few samples antibodies from patients infected with B variants circulating in Brazil and Thailand that reacted specifically. The assays described in this study are relatively rapid and simple to perform compared to molecular approaches and can be used to screen large numbers of serum or plasma samples. Moreover, the classification in subtypes (genotypes) may overestimate HIV-1 diversity and a classification into serotypes, based on antigenic V3 diversity or another principal neutralization domain, may be more helpful for vaccine development and identification of variants.

\section{Introduction}

Human immunodeficiency virus type 1 (HIV-1) is highly variable in both nucleotide and amino acid sequences. The striking genetic variability of HIV-1, particularly in the for concern in the development of a broadly hypervariable regions, is a potential cause

\section{Key words}

- HIV-1

- Viral diversity

- Serotypes

- V3 serology protective vaccine.

Phylogenetic analyses of gp 120 sequences have shown that HIV-1 can be classified into multiple genetic clades or subtypes (1). HIV1 strains fall into two major clusters. One cluster (group M) comprises the majority of HIV-1 isolates and can be divided into at least eight distinct A-I subtypes. Amino acid 
sequence variation generally ranges from 5 to $20 \%$ within a subtype and from 25 to $35 \%$ between subtypes (1). A second cluster, termed group $\mathrm{O}$ (found in Cameroon and elsewhere), differs from group $\mathrm{M}$ viruses at more than $50 \%$ of residues in the gp 120 .

The development of simple and rapid techniques for large-scale HIV-1 subtype characterization in specific areas is valuable in order to better understand the epidemiology of HIV-1 distribution, which may facilitate the evaluation of potential candidate HIV-1 vaccines and nucleic acid sequencing is the technique of choice for HIV-1 characterization (2). However, alternative techniques have been tested, including heteroduplex mobility assay (HMA), restriction fragment length polymorphism, and oligonucleotide probe hybridization (3). However, these methods do require a PCR apparatus, a fact that impairs their use in large numbers of samples or in developing countries such as Brazil. Several groups have been working to set up an enzyme immunoassay (EIA) which uses synthetic peptides in order to subtype HIV-1 by serological methods (4-7). Most of these studies have used synthetic peptides representing the hypervariable $\mathrm{V} 3$ region of the HIV-1 envelope. Unfortunately, HIV-1 subtypes present broad cross-reactivity when this approach is used $(4,6,7)$.

The reason for the use of the V3 loop of gp120 is because it contains linear epitopes for both neutralizing antibodies and cytotoxic $\mathrm{T}$ cell recognition and it is an important determinant in fusion, cell tropism, infectivity and interaction with the HIV-1 co-receptors CCR-5 and CXCR-4 (4-6). The objective of this study was to assess the specificity and sensitivity of a modified EIA using synthetic peptides derived from the $\mathrm{V} 3$ region of gp120 for serotyping.

\section{Material and Methods}

The N-terminal biotinylated peptides used in the study were synthesized by F-moc chemistry purified to $>95 \%$ by HPLC and are shown in Figure 1. The immunodominant 15 -amino acid region of $\mathrm{V} 3$ was determined in previous experiments using an overlapping V3 peptide set derived from the MN strain of HIV-1 (data not shown). The Brazilian BR2 peptide shown in Figure 1 represents a consensus sequence of one of the two genetic and antigenic subtype $B$ variants that co-circulate in Brazil (7). The use of avidinbiotin interaction improves the antigen conformation in the well, allowing a tighter antibody binding to the peptide (data not shown).

The EIA procedure was a modification of the method of Brostrom et al. (8). Briefly, microplates (Immulon II round bottom) were coated with avidin DX (Vector Laboratories, Burlingame, CA, USA) diluted in PBS, $\mathrm{pH} 7.4$, at $10 \mu \mathrm{g} / \mathrm{ml}$ overnight at $4^{\circ} \mathrm{C}$. Biotinylated peptides representing consensus sequences from the $\mathrm{V} 3$ region of clades $\mathrm{A}$ through $\mathrm{F}$ (Figure 1) were diluted to $1 \mu \mathrm{g} / \mathrm{ml}$ in PBS, pH 7.4, $0.1 \mathrm{ml}$ in each well and the plates were incubated overnight at $4^{\circ} \mathrm{C}$. The plates were washed five times with PBS plus $0.05 \%$ Tween 20 (PBS-T), blocked with PBS containing $5 \%$ dry milk without Tween for $1 \mathrm{~h}$ at $37^{\circ} \mathrm{C}$, and washed five times with PBS-T. Serial serum dilutions $(0.1 \mathrm{ml} /$ well $)$ in PBS containing 5\% dry milk and $0.05 \%$
Figure 1. Amino acid sequences of the synthetic peptides of the V3 loop of HIV-1 gp120. Cons: consensus sequences of the amino acids representative of their respective subtypes or strains. Dots indicate homology. All peptides contain a biotinSGSG sequence in their amino terminal region.

\begin{tabular}{|c|c|c|c|c|c|c|c|c|c|c|c|c|c|c|c|c|}
\hline Cons A & $\mathrm{N}$ & T & $\mathrm{R}$ & K & $\mathrm{S}$ & V & $\mathrm{R}$ & 1 & G & $P$ & G & $\mathrm{Q}$ & A & $\mathrm{F}$ & $Y$ & $\begin{array}{c}\text { Homology } \\
(100 \%)\end{array}$ \\
\hline Cons B & . & . & . & . & . & I & $\mathrm{H}$ & . & . & . & . & $\mathrm{R}$ & . & . & . & 87 \\
\hline BR2 & . & . & . & . & . & . & . & M & . & W & . & $\mathrm{R}$ & . & . & . & 87 \\
\hline Cons C & . & . & . & . & . & I & . & . & . & . & . & . & $\mathrm{T}$ & . & . & 67 \\
\hline Cons D & . & . & . & Q & $\mathrm{R}$ & $\mathrm{T}$ & $\mathrm{H}$ & . & . & . & . & . & . & L & . & 80 \\
\hline Cons $\mathrm{E}$ & . & . & . & $\mathrm{T}$ & . & I & $\mathrm{T}$ & . & . & . & . & . & V & . & . & 93 \\
\hline Cons $\mathrm{F}$ & . & . & . & . & . & I & $\mathrm{H}$ & L & . & . & . & . & . & . & . & 93 \\
\hline
\end{tabular}


Tween 20 (Blotto) were then added (six 4fold dilutions starting at 1:100) and incubated for $1 \mathrm{~h}$ at $37^{\circ} \mathrm{C}$. All assays included a human HIV-1 positive plasma pool as control. Each plate was run in duplicate and one replicate plate was washed five times with PBS-T, and the other was washed five times with PBS-8 M urea. Peroxidase-labeled antihuman IgG (Kirkegaard and Perry Lab. Inc., Gaithersburg, MD, USA) diluted 1:10,000 in Blotto, $0.1 \mathrm{ml} /$ well, was incubated for $1 \mathrm{~h}$ at $37^{\circ} \mathrm{C}$, and the plates were washed five times with PBS-T. The plates were incubated with $0.15 \mathrm{ml} /$ well of TMB substrate for $30 \mathrm{~min}$ at room temperature, and the reaction was stopped with $0.05 \mathrm{ml} /$ well of 4 $\mathrm{NH}_{2} \mathrm{SO}_{4}$. The plates were read with a spectrophotometer at $450 \mathrm{~nm}$ and the endpoint titer was calculated as the interpolated dilution yielding a mean absorbance of 0.5 by linear regression. The dilution obtained by linear regression was used to calculate the avidity index [(urea titer/PBS titer) $x$ 100]. Thus, the immunodominant subtype is determined by the highest avidity index obtained (9).

Samples classified as indeterminate or that cross-reacted with more than one consensus peptide (subtype) when tested by urea EIA were tested by a modified competition EIA as reported by Sherefa et al. (10). Briefly, microplates (Immulon II round bottom) were coated with avidin DX (Vector) diluted in PBS, pH 7.4, at $10 \mu \mathrm{g} / \mathrm{ml}$ overnight at $4^{\circ} \mathrm{C}$. A mixture of biotinylated peptides A through $\mathrm{F}$ was diluted in PBS to $0.2 \mu \mathrm{g} / \mathrm{ml}$ each (final concentration $1.2 \mu \mathrm{g} /$ well) and $0.1 \mathrm{ml} /$ well was added. The plates were incubated overnight at $4{ }^{\circ} \mathrm{C}$ and washed five times with PBS-T. Each serum was diluted 1:50 in Blotto and added to seven wells at $0.05 \mathrm{ml} /$ well. A $0.05-\mathrm{ml}$ aliquot of a single subtype specific $\mathrm{V} 3$ peptide diluted to $5 \mu \mathrm{g} / \mathrm{ml}$ in Blotto was added to each well and the plates were incubated for $1 \mathrm{~h}$ at $37^{\circ} \mathrm{C}$. A non-inhibited control containing only dilution buffer was included. Peroxidase-labeled anti-human IgG, substrate and stop reaction were used as described above. Samples with $>50 \%$ inhibition by their respective peptide were considered to be the subtype (10).

Thirty-one sera were obtained from the WHO Network for HIV Isolation and Characterization (11). They were collected from four WHO-sponsored vaccine sites [Brazil $(\mathrm{N}=12)$, Thailand $(\mathrm{N}=9)$, Uganda $(\mathrm{N}=7)$, and Rwanda $(\mathrm{N}=3)$ ]. We also tested 38 sera from Harare city, Zimbabwe and 43 sera from Pune city, India. The genotype of the infecting virus was determined by direct sequencing and/or HMA analysis (11). All samples were tested and the results were interpreted in a blind fashion with respect to genotype.

\section{Results}

The degree of amino acid homology between the peptides used is shown in Table 1. When conservative amino acid substitutions were used the consensus $\mathrm{A}$ and $\mathrm{C}$ peptides were $100 \%$ homologous. The consensus $\mathrm{F}$ peptide was $93 \%$ homologous to the $\mathrm{A}, \mathrm{B}$,

Table 1. Amino acid homology in the synthetic peptides.

\begin{tabular}{|c|c|c|c|c|c|c|c|}
\hline \multicolumn{8}{|c|}{ Percent homology ${ }^{1}$} \\
\hline & A & $B$ & Bw & $\mathrm{C}$ & $\mathrm{D}$ & $E$ & $F$ \\
\hline \multicolumn{2}{|l|}{ A } & 80 & 67 & 87 & 67 & 73 & 80 \\
\hline B & 87 & & 87 & 80 & 67 & 73 & 87 \\
\hline $\mathrm{Bw}^{3}$ & 80 & $93^{2}$ & & 67 & 53 & 60 & 80 \\
\hline C & 100 & 87 & 80 & & 60 & 80 & 80 \\
\hline D & 67 & 67 & 60 & 67 & & 60 & 67 \\
\hline $\mathrm{E}$ & 80 & 73 & 67 & 80 & 60 & & 73 \\
\hline $\mathrm{F}$ & 93 & 93 & 87 & 93 & 73 & 80 & \\
\hline \multicolumn{8}{|c|}{$\begin{array}{l}{ }^{1} \text { Numbers at upper right indicate absolute homology in percent (shaded boxes), and } \\
\text { numbers at lower left indicate homology in percent with conservative changes al- } \\
\text { lowed (no protein modification). } \\
{ }^{2} \text { Homology }>90 \% \text { is shown in bold. } \\
{ }^{3} \mathrm{~V} 3 \text { peptide representing Brazilian variant subtype B (GWGR motif). }\end{array}$} \\
\hline
\end{tabular}


and $\mathrm{C}$ peptides.

Table 2 shows the results of the serotyping assays with 112 sera from individuals infected with viruses of subtypes A-F. For

Table 2. EIA V3 serotyping using samples from subtypes A-F of HIV-1 compared to results obtained by HMA and DNA sequencing.

\begin{tabular}{ccccccccc}
\hline Subtype & \multicolumn{7}{c}{ V3 serology } & \multirow{2}{*}{ Total (N = 112) } \\
\cline { 2 - 7 } & A & B & C & D & E & F & NT & \\
\hline A & 3 & 1 & 2 & - & - & - & - & 6 \\
B & - & 7 & - & - & - & - & - & 7 \\
C & 2 & - & 76 & - & - & 1 & 1 & 80 \\
D & 1 & 1 & - & 3 & - & - & - & 5 \\
E & - & - & - & - & 7 & - & - & 7 \\
F & 2 & 3 & - & - & - & 2 & - & 7 \\
\hline
\end{tabular}

NT: Not typable. Samples with reactivity similar $(50 \%)$ to more than one peptide.

Table 3. Comparison of sensitivity, specificity and predictive values between V3 serology and HMA/genotype.

\begin{tabular}{lllll}
\hline Subtype & \multicolumn{4}{c}{ V3 serology } \\
\cline { 2 - 5 } & Sensitivity & Specificity & PPV & NPV \\
\hline A & 0.5 & 0.95 & 0.91 & 0.64 \\
B & 1.0 & 0.95 & 0.20 & 1.0 \\
C & 0.95 & 0.94 & 0.93 & 0.65 \\
D & 0.6 & 1.0 & 1.0 & 0.71 \\
E & 1.0 & 1.0 & 1.0 & 1.0 \\
F & 0.28 & 0.99 & 0.96 & 0.12 \\
\hline
\end{tabular}

Values $>0.7$ are given in bold. V3 serology using $8 \mathrm{M}$ urea plus competition assay. PPV: positive predictive value; NPV: negative predictive value.

Table 4. Results obtained by HMA, EIA-peptide, and EIA-peptide competition in samples from India and Zimbabwe.

\begin{tabular}{lcccc} 
& HMA & \multicolumn{3}{c}{ V3 serology } \\
\cline { 3 - 5 } & & Urea & Competitive & Corrected \\
\cline { 3 - 5 } & \multirow{2}{*}{ India } & $40 \mathrm{C}, 1 \mathrm{C} / \mathrm{F}$ & ND & $40 / 41$ (98\%) \\
Zimbabwe & $38 \mathrm{C}$ & $27 \mathrm{C}$ & ND & \\
& & 6 Und & $6 \mathrm{C}$ & \\
& & $3 \mathrm{~A} / \mathrm{C}$ & $1 \mathrm{C}, 1 \mathrm{C} / \mathrm{A}, 1$ Und \\
& $1 \mathrm{C} / \mathrm{B}$ & $1 \mathrm{C}$ & \\
Total & $1 \mathrm{C} / \mathrm{E}$ & $1 \mathrm{~A}$ & $35 / 38$ (92\%)
\end{tabular}

HMA: heteroduplex mobility assay; ND: not done; Und: undetermined. Percent corrected using urea and competitive assay results.
32 sera, the V3 sequence of the infecting virus was determined and the percent homology with the consensus peptides was calculated (data not shown). In addition, sera from recently seroconverted individuals showed a higher specific reactivity to the V3 peptides compared to sera from individuals whose viral sequences showed a high degree of homology with the homologous peptide (data not shown).

Table 2 summarizes the results obtained using V3 serology. The subtype A sera were not from recently infected individuals. The subtype B sera were all correctly typed by the assay as was the HIV+ plasma pool control obtained from individuals in California, USA. The two B peptides also differentiated individuals infected with viruses containing either GPGR (data not shown) or GWGR sequences at the tip of the V3 loop, in agreement with a larger study conducted in Brazil $(12,13)$. Three of six subtype A sera $(50 \%)$ and seven subtype B sera (3 from Thailand and 4 from Brazil) were correctly typed $(100 \%)$. However, only three of the five subtype D (60\%) sera from Uganda were typed correctly. Thus, the overall level of homology between viral and peptide sequences was low and these sera were considered to be most likely from individuals with long-term infection. Seven of 7 subtype E $(100 \%)$ sera from Thailand were correctly typed. The seven subtype F sera from Brazil showed patterns of cross-reactivity (A and B) consistent with the predictions described in Table 1, and only two sera were correctly typed (28\%). One subtype C from Brazil was correctly typed.

Table 3 summarizes the sensitivity and specificity data for the V3 serology assays. For subtypes B, C and E, the sensitivity was more than $80 \%$. In contrast, for subtypes A, $\mathrm{D}$ and $\mathrm{F}$, the assay was not adequate. These calculations are likely to be imprecise since only a few samples were analyzed for some subtypes.

Table 4 describes the results obtained for 
subtype $\mathrm{C}$ by HMA among the 41 samples from India (98\% HIV-1 C using V3 serology) and 38 from Zimbabwe ( $92 \%$ correctly typed by V3 serology). No samples from India needed to be tested by the competitive assay, whereas 11 Zimbabwean samples required testing by this approach. Thus, these results revealed that subtype $\mathrm{C}$ discrimination by V 3 serology was slightly easier among samples from India.

Table 5 depicts the results of subtype $\mathrm{C}$ with regard to the time of infection. A sample was considered to be recent when taken less than one year after infection, and late when taken more than one year after infection. Thus, 42 of 50 (84\%) seroconverters were correctly serotyped by V3 serology as subtype $\mathrm{C}$ and eight (16\%) were undetermined. Among 30 sera from late infected individuals, 25 (84\%) were correctly identified as subtype $\mathrm{C}$ by $\mathrm{V} 3$ serology and five $(16 \%)$ were undetermined. Therefore, the time of infection did not alter the sensitivity or specificity of HIV-1 C subtyping in Harare and Pune.

\section{Discussion}

The most common procedures used for HIV-1 subtyping are sequence analysis and HMA. Both methods are relatively expensive and labor intensive and require cellular nucleic acid, limiting their usefulness in developing countries and in larger population studies. We have developed a modified V3 peptide EIA that can discriminate accurately some HIV-1 subtypes, such as B, C, E and a variant of the subtype $B$ from Brazil and Thailand. Previous studies using synthetic peptides derived from V3 sequences have given variable results in their ability to distinguish HIV-1 subtypes (12-15). Our modified V3 EIA showed similar sensitivity and specificity for some HIV-1 subtypes (1417). Thus, V3 serology may be more reliable to evaluate the distribution of the intrasubtype strains, such as the Brazilian or Thai B vari- ants.

The development of an EIA using biotinylated peptides captured onto the solid phase and the use of an 8-M urea wash to reveal high avidity antibody interactions permit more accurate detection of subtype-specific antibody responses, particularly with subtypes B, C and E. In addition, the use of competitive EIA as a supplementary test permitted further resolution of specificity for some samples that yielded indeterminate results by urea EIA.

Both time since seroconversion and degree of sequence homology between the peptides and the infecting viral type affected the specificity of the assay. The cross-reactivity observed in sera from some individuals might result from increased frequency of quasispecies seen in the late phases of HIV infection (18). In general, the antibody avidity is directly related to the duration of infection. Even though we did not find statistical difference between the subtype $\mathrm{C}$ circulating in India and Zimbabwe, this subtype from India showed slightly greater specificity compared to HMA results for those obtained from Zimbabwe. One possible explanation may be the more recent introduction of HIV1 in India, which results in greater V3 sequence conservation as shown by Salminen et al. (18).

Genotype classification may either overestimate or underestimate the degree of antigenic variability as measured by V3 serol-

Table 5. V3 serology in samples typed as subtype $\mathrm{C}$ by HMA in samples from Zimbabwe and India.

\begin{tabular}{lcc} 
Time of infection & \multicolumn{2}{c}{ EIA results [N (\%)] } \\
\cline { 2 - 3 } & Subtype C & Undetermined \\
\hline Recent $^{1}(\mathrm{~N}=50)$ & $42(84 \%)$ & $8(16 \%)$ \\
Long $^{2}(\mathrm{~N}=29)$ & $25(86 \%)$ & $4(14 \%)$ \\
Total $(\mathrm{N}=79)$ & $67(85 \%)$ & $12(15 \%)$ \\
\hline
\end{tabular}

${ }^{1}$ Recent: $<1$ year of infection.

2Long lasting: $>1$ year of infection. 
ogy. Different genotypes may have evolved by mutations in regions other than those that determine epitopes for antibody responses, resulting in an overestimation of antigenic differences by genetic classification. Conversely, real antigenic differences within genotypically defined subgroups may also exist, as in the case of two antigenically distinct strains of subtype B present in Brazil $(7,12)$. It has been reported that subtypes A and D show high levels of intrasubtype variability (19). A high degree of homology exists between subtypes $\mathrm{B}$ and $\mathrm{F}$ within the 15 -amino acid sequence represented by the peptides used in this study, thus precluding differentiation between subtypes B and F. We should emphasize that the EIA assay used here does not discriminate between subtypes $\mathrm{B}$ and $\mathrm{F}$, and further improvement of the assay will be necessary to increase its specificity, by using longer or alternative peptides based on Brazilian subtype F sequences (13). Another limitation of V3-based serology is the existence of intersubtype recombinants of subtype F in Brazil, suggesting that it is more likely to represent a mosaic virus, similar to the HIV-1 E/A in Thailand (19-21).

It has been suggested that subtypes A, D, and $\mathrm{F}$, which were the most difficult to be typed by V3 serology, may be specifically subtyped using another region of the env gene, such as a synthetic peptide from gp41 (22). Moore et al. (23) demonstrated that the presence of non-ionic detergent in the antibody diluent affected the specificity and sensitivity of V3 peptide EIA. However, we did not observe any difference in the sensitivity or specificity of the avidin capture assay in the presence or absence of Tween 20 for several sera from subtype B- or C-infected individuals (data not shown).

The V3 serology assays, even though with some limitations (24), are rapid and simple to perform compared to molecular assays, and can be used to screen large numbers of serum or plasma samples in settings where HMA or sequence analysis is not practical. Also, this assay could be used to monitor the introduction of new strains (antigenic variants) and changes in the epidemic pattern of subtypes in the community (surveillance) in large epidemiological studies.

We have also demonstrated a $70 \%$ correlation between high avidity antibodies by the V3 serology and virus neutralization both in HIV-1 vaccinees and recent seroconverters (Casseb J, Duarte AJS and Hendry RM, unpublished results). Further studies with expanded serum panels from different geographic regions, using expanded panels of peptides, should be done. Future studies examining the relationships between $\mathrm{V} 3$ serology, virus neutralization and genotypic classification will help define the antigenic variability of HIV and its importance in the natural history of HIV disease as well as in vaccine design.

\section{Acknowledgments}

We thank Deepak Gadkari for providing serum samples from Pune, India.

\section{References}

1. Myers G, Korber B, Wain-Hobson S, Smith R \& Pavlakis G (1995). A compilation and analysis of nucleic acid and amino acid sequences. In: Myers G (Editor), Human Retroviruses and AIDS. Los Alamos National Laboratory, Los Alamos, NM, USA.

2. Delwart EL, Shpaer EG, Louwagie J, McCutchan FE, Grez M, Rübsamen-
Waigmann H \& Mullins J (1993). Genetic relationships determined by a DNA heteroduplex assay: analysis of HIV-1 env gene. Science, 262: 1257-1261.

3. Workshop Report from the European Commission and the J oint United Nations Programme on HIVIAIDS (1997). HIV-1 subtypes: implications for epidemiology, pathogenicity, vaccines and diagnostics. AIDS, 11: 17-36.

4. Choe $H$, Farzan $M$, Sun $Y$, Sullivan $N$, Rollins B, Ponath PD, Wu L, Mackay CR, LaRosa G, Newman W, Gerard N, Gerard C \& Sodrosky J (1996). The ß-chemokine receptors CCR3 and CCR5 facilitate infection by primary HIV-1 isolates. Cell, 85: 
1135-1148.

5. Unutmaz D \& Littman DR (1997). Expression pattern of HIV-1 coreceptors on T cells: Implications for viral transmission and lymphocytes homing. Proceedings of the National Academy of Sciences, USA, 94: 1615-1618.

6. Bleul CC, Wu L, Hoxie J A, Springer TA \& Mackay CR (1997). The HIV coreceptors CXCR4 and CCR5 are differentially expressed and regulated on human $T$ lymphocytes. Proceedings of the National Academy of Sciences, USA, 94: 19251930.

7. Morgado MG, Sabino EC, Shaer EG, Bongertz V, Brigido L, Guimarães MDC, Castilho EA, Galvão-Castro B, Mullins J I, Hendry RM \& Mayer A (1994). V3 region polymorphisms in HIV-1 from Brazil: Prevalence of subtype $B$ strains divergent from North American/European protype and detection of subtype F. AIDS Research and Human Retroviruses, 10: 569576.

8. Brostrom C, Sonnenberg A \& Sallberg M (1995). Human immunodeficiency virus (HIV) type 1-infected patients with no disease progression display high-avidity production to autologous v3 sequences. J ournal of Infectious Diseases, 171: 509511.

9. Binley J M, Arshad H, Fouts TR \& Moore J P (1997). An investigation of the highavidity antibody response to glycoprotein 120 of human immunodeficiency virus type 1. AIDS Research and Human Retroviruses, 13: 1007-1015.

10. Sherefa K, Sonnenberg A, Steinbergers J \& Sallberg M (1994). Rapid grouping of HIV-1 infection in subtypes A to E by V3 peptides serotyping and its relation to sequence analysis. Biochemical and Biophysical Research Communications, 205: 1658-1664.

11. WHO Network for HIV Isolation and Characterization (1994). HIV type 1 variation in World Health Organization-sponsored vaccine evaluation sites: Genetic screening, sequence analysis, and preliminary biological characterization of selected viral strains. AIDS Research and Human Retro- viruses, 10: 1327-1343.

12. Hendry RM, Hanson CV, Bongertz V, Morgado M, Duarte A, Casseb J, Brigido L, Sabino E, Diaz R \& Galvão-Castro B (1996). Immunoreactivity of Brazilian HIV isolates with different V3 motifs. Memórias do Instituto Oswaldo Cruz, 91: 347348.

13. Casseb J , Hong MA, Gonsalez C, Brígido LF, Duarte AJ S \& Hendry RM (1998). Two variants of HIV-1 B serotype are transmitted heterosexually in São Paulo, Brazil. Brazilian J ournal of Medical and Biological Research, 31: 1243-1246.

14. Murphy G, Belda FJ , Pau C-P, Clewley JP \& Perry J V (1999). Discrimination of subtype B and non-subtype B strains of human immunodeficiency virus type 1 by serotyping: correlation with genotyping. J ournal of Clinical Microbiology, 37: 13561360.

15. Cheingsong-Popov R, Lister $\mathrm{S}$, Callow $\mathrm{P}$, Kaleebu P, Beddowos S, Weber J \& the WHO Network for HIV Isolation and Characterization (1994). Serotyping HIV type 1 by antibody binding to the V3 loop: Relationship to viral genotype. AIDS Research and Human Retroviruses, 10: 1379-1386.

16. Barin $F$, Lahbabi Y, Buzelaay L, Lejeune $B$, Baillou-Beaufils A, Denis F, Mathiot $C$, M'Boup S, Vithayasai V, Dietrich U \& Goudeau A (1996). Diversity of antibody binding to V3 peptides representing consensus sequences of HIV type 1 genotypes A to E: An approach for HIV type 1 serological subtyping. AIDS Research and Human Retroviruses, 12: 1279-1289.

17. Nkengasong J N, Willems $B$, J anssens $W$, Cheingsong-Popov R, Heyndrickx L, Barin F, Ondoa P, Fransen K, Goudsmit J \& Van der Groen G (1998). Lack of correlation between V3-loop peptide enzyme immunoassay serologic subtyping and genetic sequencing. AIDS, 12: 1405-1412.

18. Salminen $M O$, J ohansson $B$, Sonnenberg A, Ayehunie S, Gotte D, Leinikki P, Burke DS \& McCutchan FE (1996). Full-length sequence of an Ethiopian human immunodeficiency virus type 1 (HIV-1) isolate of genetic subtype C. AIDS Research and Human Retroviruses, 12: 1329-1339.
19. Gao F, Morrison SG, Robertson DL, Thornton CL, Craig S, Karlsson G, Sodroski J , Morgado M, Galvão-Castro B, von-Briesen $\mathrm{H} \&$ the WHO Network for HIV Isolation and Characterization (1996). Molecular cloning and analysis of functional envelope genes from human immunodeficiency virus type 1 sequence subtypes A through G. The WHO and NIAID Networks for HIV Isolation and Characterization. J ournal of Virology, 70: 16511667.

20. Douglas NW, Knight Al, Holmes $H$, Hayhurst A, Barrett WY \& Daniels RS (1996). An efficient method for the rescue and analysis of functional HIV-1 env genes: evidence for recombination in the vicinity of the tat/rev splice site. AIDS, 10: 39-46.

21. Tanuri A, Swanson P, Devare S, Berro OJ , Savedra A, Costa LJ , Telles J G, Brindeiro $R$, Schable C, Pieniazek D \& Rayfield M (1999). HIV-1 subtypes among blood donors from Rio de J aneiro, Brazil. J ournal of Acquired Immune Deficiency Syndrome, 20: 60-66.

22. Cheingsong-Popov R, Osmanov S, Pau C$P$, Schochetman G, Barin F, Holmes $H$, Franis G, Ruppach H, Dietrich U, Lister S, Weber J \& the UNAIDS Network for HIV-1 Isolation and Characterization (1998). Serotyping of HIV-1 infections: Definition, relationship to viral genetic subtypes, and assay evaluation. AIDS Research and Human Retroviruses, 14: 311317.

23. Moore J P, Trkola A, Korber B, Boots LJ , Kessler] A, McCutchan FE, MascolaJ , Ho DD, Robinson J \& Conley AJ (1995). A human monoclonal antibody to a complex epitope in the V3 region of gp120 of human immunodeficiency virus type 1 has broad reactivity within and outside clade B. J ournal of Virology, 69: 122-130.

24. Plantier J -C, Damond F, Lasky M, Sankalé J $L$, Apetrei C, Peeters M, Buzelay L, M'Boup S, Kanki P, Delaporte E, Simon F \& Barin F (1999). V3 serotyping of HIV-1 infection: Correlation with genotyping and limitations. AIDS Research and Human Retroviruses, 20: 432-441. 